\title{
Antimicrobial activity of bergenin from Endopleura uchi (Huber) Cuatrec.
}

\author{
Saulo L. da SILVA¹, Viviane Guedes de OLIVEIRA², Tomomasa YANO³, Rita de Cássia Saraiva \\ NUNOMURA $^{4}$
}

\begin{abstract}
Endopleura uchi (Huber) Cuatrec. is an Amazon species traditionally used as treatment for inflammations and female disorders. Bergenin was isolated from ethyl acetate fraction of bark of $E$. uchi by using column chromatography over sephadex LH-20 and then silica gel 60 flash. Its structure was identified on the basis of its NMR spectra. The antimicrobial activity of bergenin and fractions of methanol extract of E. uchi were evaluated against ATCC microorganisms (Escherichia coli, Salmonella enteritidis, Pseudomonas aeruginosa, Enterococcus faecalis, Staphylococcus aureus, Candida albicans, C. guilliermondii, Aspergillus flavus, A. nidulans). Clinically isolated strains of all of these microorganisms, along with C. tropicalis, A. niger, Shigella sonnei, Serratia marcenses and Klebsiella pneumoniae were also evaluated. The growth inhibition caused by bergenin, extracts and fractions of E. uchi against ATCC microorganisms were similar to the inhibition to microorganisms clinically isolated. The ethyl acetate fraction and the isolate bergenin inhibit the growth of the yeasts $C$. albicans, C. tropicalis, and C. guilliermondii, but present lower activity against filamentous fungi Aspergillus flavus, A. nidulans, A. niger, and did not inhibit the Gram positive and Gram negative bacteria. The activity of the ethyl acetate fraction and bergenin are in agreement wit its high concentration found in bark extract of E. uchi. Moreover, the selective activity against three Candida species helps to understand its traditional use against infections that affect women.
\end{abstract}

KEYWORDS: Antibacterial, Antifungal, Candida, Humiriaceae, Uxi-amarelo.

\section{Atividade antimicrobiana de bergenina isolada de Endopleura uchi (Huber) Cuatrec.}

\begin{abstract}
RESUMO
Endopleura uchi (Huber) Cuatrec. é uma espécie amazônica utilizada tradicionalmente para o tratamento de inflamações uterinas e outras afecçôes femininas. Das cascas de E. uchi foi isolada a substância bergenina, por meio de cromatografia em coluna usando como fases estacionárias sephadex LH-20 e posteriormente, sílica gel 60 flash. A identificação estrutural de bergenina foi realizada por meio de espectros de RMN. A avaliação da atividade antimicrobiana da bergenina, dos extratos e frações de E. uchi foi realizada contra microorganismos ATCC e clinicamente isolados (Escherichia coli, Salmonella enteritidis, Pseudomonas aeruginosa, Enterococcus faecalis, Staphylococcus aureus, Candida albicans, C. guilliermondii, Aspergillus flavus, A. nidulans). Além desses, foram testados os microorganismos isolados clinicamente (C. tropicalis, A. nidulans, A. niger, Shigella sonnei, Serratia marcenses, Klebsiella pneumoniae e Enterococcus faecalis). A inibição de crescimento dos microorganismos pela bergenina e extratos e frações de E. uchi contra os microorganismos ATCC foram similares à inibição obtida contra microorganimos isolados clinicamente. Os resultados revelaram a bergenina como um inibidor seletivo de Candida albicans, C. tropicalis e C. guilliermondii. Porém, a bergenina apresentou uma atividade inferior contra os fungos Aspergillus flavus, A. nidulans, A. niger, e não inibiu o crescimento de bactérias Gram positivas e Gram negativas. As atividades da fração de acetato de etila e da bergenina pura estão em concordância com a concentração da bergenina nas cascas. A atividade seletiva de bergenina contra três espécies de Candida auxilia na compreensão do seu uso tradicional contra que infecções que afetam o aparelho reprodutor feminino.
\end{abstract}

PalaVRaS-Chave: Antibacteriano, Antifúngico, Candida, Humiriaceae, Uxi-amarelo

\footnotetext{
1 Universidade Federal de São João Del Rei - UFSJ. Centro de Ciências da Saúde - Campus Divinópolis. Av. Sebastião Gonçalves Coelho, 400. Bairro Chanadour, CEP 35501 -296 Divinópolis - MG - Brasil. e-mail: biomol2@hotmail.com

2 Coordenação de Pesquisas em Produtos Naturais (CPPN), Instituto Nacional de Pesquisas da Amazônia, INPA, CEP 69083-000, Manaus, AM, Brazil. e-mail: nani_guedes@hotmail.com

${ }^{3}$ Departamento de Microbiologia, Instituto de Biologia (IB), Universidade Estadual de Campinas, UNICAMP, CEP 13081-970, Campinas, SP. Brazil. e-mail: tyano@unicamp.br

${ }^{4}$ Coordenação de Pesquisas em Produtos Naturais (CPPN), Instituto Nacional de Pesquisas da Amazônia, INPA, CEP 69083-000, Manaus, AM, Brazil. e-mail: ritags@inpa.gov.br
} 


\section{INTRODUCTION}

Endopleura uchi (Huber) Cuatrec. (Humiriaceae) is a species widely spread in the Amazon basin, popularly known as "uxi-amarelo" or "uxi-liso". There are few chemical studies of E. uchi and are concentrated in the fruits that are very appreciated in the region. The pulp of the fruit has a high content of fat, predominantly oleic acid (Marx et al., 2002) and carotenoids, mostly trans- $\beta$-carotene (Magalhães et al., 2007). However is the bark tea of E. uchi that is used in the traditional medicine as an anti-inflammatory, also against tumors, and uterine infections (Corrêa, 1984, Revilla, 2001). We isolated bergenin, a derivative of $C$-glycoside of 4-O-methyl gallic acid, from the bark. Previously bergenin had also been isolated from E. uchi fruits (Magalhães et al., 2007) and also many other species, including species of the family as Humiria balsamifera (Caldas et al., 2002) and Sacoglottis gabonensis (Ogan, 1971). Bergenin presents several biological activities such as anti-inflammatory (Swarnalakshmi et al., 1984; Nazir et al., 2007), antioxidant (Sumino et al., 2002), hepatoprotective (Lim et al., 2000), neuroprotective (Takahachi et al., 2003), and anti-HIV (Piacente, 1996). Bergenin also presents antifungal activity against some plant pathogenic fungi (Prithiviraj et al., 1997) Hereby, we report the antimicrobial activity of bergenin against ATCC and clinically isolated microorganisms Escherichia coli, Salmonella enteritidis, Pseudomonas aeruginosa, Enterococcus faecalis, Staphylococcus aureus, Candida albicans, Candida guilliermondii, Aspergillus flavus, Aspergillus nidulans. Also some clinically isolated microorganisms (C. tropicalis, Aspergillus flavus, A. nidulans, A. niger, Shigella sonnei, Serratia marcenses and Klebsiella pneumoniae) were evaluated.

\section{MATERIAL AND METHODS}

\section{PLANT MATERIAL}

The barks of E. uchi were collected in December of 2005, in Adolpho Ducke Reserve (INPA) located $23 \mathrm{Km}$ from Manaus (AM), and identified by G. T. Prance. Voucher specimens were deposited in the INPA herbarium with numbers 177673 and 177660 .

\section{PREPARATION OF AQUEOUS EXTRACT}

The aqueous extract was prepared by decoction of $30 \mathrm{~g}$ of bark in $500 \mathrm{~mL}$ of water, boiling for 5 minutes and then was concentrated by low pressure. The yield of extract was $13.3 \%$.

\section{EXTRACTION AND ISOLATION OF BERGENIN}

All solvents used for the extraction and isolation were analytical grade. Air-dried powdered trunk bark $(2.9 \mathrm{Kg})$ was extracted by maceration in hexanes for 3 weeks and the

solvent replaced 3 times. The extracts were concentrated until dryness and $4.8 \mathrm{~g}$ of hexane extract was obtained. After extraction in hexanes, the barks were extracted with methanol for 3 weeks and the solvent replaced 3 times, then the extracts were concentrated under vacuum and yielded $266.8 \mathrm{~g}$ of extract in methanol. The methanol extract (110.0 g) was redissolved in $\mathrm{MeOH} / \mathrm{H}_{2} \mathrm{O}(9: 1)$ and partitioned into hexanes, chloroform, and ethyl acetate. The four resulting fractions were concentrated under mild conditions until dry and yielded 1.1, 6.5, 39.6, and $62.0 \mathrm{~g}$ of hexanes, chloroform, ethyl acetate, and hidroalcoholic fraction, respectively. By fractionated solubilization of the ethyl acetate fraction with methanol, it was possible to separate it into a soluble fraction (SEA) that yielded $30.66 \mathrm{~g}$, and $8.94 \mathrm{~g}$ of a non-soluble fraction (NSEA). After concentrated, $1.0 \mathrm{~g}$ of the non-soluble material was purified over Sephadex LH-20 column eluted with methanol and afforded 22 fractions. The first fraction was further purified over silica flash column eluted first with ethyl acetate 100\%, then ethyl acetate/methanol (9:1) and finally $\mathrm{MeOH} 100 \%$. The fractions 3 to 7, eluted with EtOAc/MeOH (9:1), were dried and recrystalized with ethyl acetate, yielding $37.0 \mathrm{mg}$ of a colorless crystal identified as bergenin.

\section{IDENTIFICATION AND CHARACTERIZATION OF BERGENIN}

Bergenin isolated from E. uchi was identified on the basis of its NMR spectra and compared with reported data in the literature (Jahodar et al., 1992). The bergenin structure is shown in Figure 1. NMR spectra were recorded on a Varian Inova-500 spectrometer. NMR data were collected at room temperature. ${ }^{1} \mathrm{H}$ NMR (500 MHz, CD 3 OD-d4): $\delta 7.09$ (s, $1 \mathrm{H}) ; 4.94(\mathrm{~d}, 10,1 \mathrm{H}) ; 3.68(\mathrm{~m}, 1 \mathrm{H}) ; 3.43(\mathrm{dd}, 9.5 ; 8.5$, $1 \mathrm{H}) ; 3.81(\mathrm{t}, 8.75 ; 8.5,1 \mathrm{H}) ; 4.07(\mathrm{t}, 9.5 ; 10.0,1 \mathrm{H}) ; 3.91$ (s, 3H); $3.68(\mathrm{~m}, 1 \mathrm{H}) ; 4.03(\mathrm{dd}, 10.7 ; 2.5,1 \mathrm{H}) .{ }^{13} \mathrm{C} \mathrm{NMR}$ (125 MHz, CD $\left.{ }_{3} \mathrm{OD}-\mathrm{d} 4\right): \delta 164.6(\mathrm{C}) ; 151.1$ (C); 141.1 (C); $148.2(\mathrm{C}) ; 116.1(\mathrm{C}) ; 118.2(\mathrm{C}) ; 109.9(\mathrm{CH}) ; 73.1$ $(\mathrm{CH}) ; 81.9(\mathrm{CH}) ; 70.7(\mathrm{CH}) ; 74.4(\mathrm{CH}) ; 80.2(\mathrm{CH}) ; 59.8$ $\left(\mathrm{OCH}_{3}\right) ; 61.5\left(\mathrm{CH}_{2}\right)$.

$<<<$

Prezado autor, verificar esta simbologia pois no original também consta assim " $\delta$ "

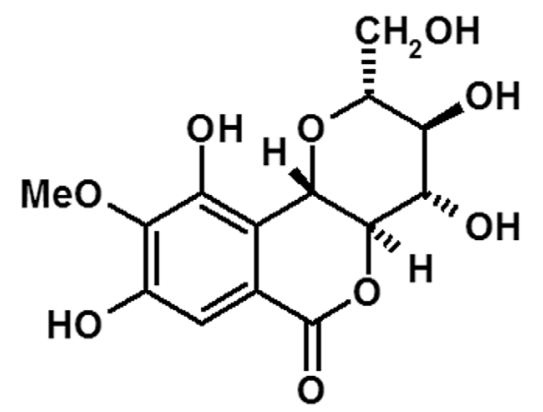

Figure 1 - Bergenin structure 


\section{MICROORGANISMS}

Some microorganisms were obtained from standard collections and others from clinical material. The standard microorganism were from American Type Culture Collection: Escherichia coli (ATCC 25922), Salmonella enteritidis (ATCC 11076), Pseudomonas aeruginosa (ATCC 27853), Enterococcus faecalis (ATCC 29212), Staphylococcus aureus (ATCC 29213), Candida albicans (ATCC 36232), Candida guilliermondii (ATCC 6260), Aspergillus flavus (ATCC 32612), Aspergillus nidulans (ATCC 28901). The isolated microorganisms were obtained from material proceeding from the State University of Campinas Hospital (Campinas, Brazil), properly identified and characterized through standard biochemical tests and stocked in the Microbiology Laboratory of the Biology Institute of the State University of Campinas (UNICAMP). The selected microorganisms from clinical material were three yeast (Candida albicans, C. tropicalis and C. guilliermondii), three filamentous fungi (Aspergillus flavus, A. nidulans and $A$. niger), six Gram negative bacteria (Escherichia coli, Salmonella enteritidis, Shigella sonnei, Pseudomonas aeruginosa, Serratia marcenses and Klebsiella pneumoniae), two Gram positive bacteria (Enterococcus faecalis and Staphylococcus aureus).

Antimicrobial tests. The bacteria were cultured on nutrient Mueller-Hinton agar slant (DIFCO, Detroit, MI), while fungi on RPMI 1640 standard cell culture (Sigma Chemicals, St. Louis, MO) were buffered with a 0.165 M MOPS buffer and fortified with $20 \mathrm{~g}$ of glucose/liter and 1.5\% agar (Hoffman \& Pfaller, 2001). Antimicrobial activity of bergenin was evaluated by the agar-well diffusion method. The test microorganisms were seeded into respective medium, in sterile Petri plates, after the medium with melted agar, sterilized by autoclaving, was cooled to about $55^{\circ} \mathrm{C}$. After hardening, $6.2 \mathrm{~mm}$ diameter wells were made in agar using a sterile borer. The wells were filled with $100 \mu \mathrm{L}$ of test solution. The tested solutions of aqueous extract (AE), soluble fraction of ethyl acetate (SEA), non-soluble fraction of ethyl acetate (NSAE) and bergenin (Berg) were obtained by serial two-fold dilutions in DMSO (dimethyl sulfoxide) of an initial sample at $5.0 \mathrm{mg} / \mathrm{mL}$. The positive control was prepared using antibiotic solutions at 1.0 $\mathrm{mg} / \mathrm{mL}$ of chloramphenicol (Chl) and streptomycin (Stp) for bacteria and miconazole (Mz) for fungi (Da Silva et al., 2006, 2008). Pure DMSO was used as the negative control. To prevent temperature changes during the tests, plates were incubated for both bacteria and fungi screening for $48 \mathrm{~h}$ at $37^{\circ} \mathrm{C}$ (Da Silva et al., 2008, Braga et al. 2008, Hussain et al., 2008). The diameter of the zones of inhibition around each well (well diameter included) was taken as a measure of the antimicrobial activity. Each experiment was carried out in triplicate and the mean diameter of the inhibition zone was taken into account. The Minimum Inhibitory Concentration (MIC) values were determined as the highest dilution of the sample to inhibit bacteria or fungi growth (NCCLS, 1990).

\section{RESULTS AND DISCUSSION}

The complete antimicrobial assays of bergenin, extracts and fractions from $E$. uchi against the tested microorganisms are shown in Table 1 . The inhibitory growth for all tested samples was similar for ATCC and clinical isolated microorganisms. In same cases, we have obtained the same values, showing the possibility to work with clinical isolated microorganisms.

Table 1 - The Minimal Inhibitory Concentration of aqueous extract (AE), soluble ethyl acetate fraction (SEA), non soluble ethyl acetate fraction (NSEA) and bergenin (Berg) against bacteria and fungi from American Type Culture Collection (ATCC) and clinical isolated material in agar diffusion method.

\begin{tabular}{|c|c|c|c|c|c|c|c|c|}
\hline & Microorganism & $\mathrm{AE}$ & SEA & NSEA & Berg & $\mathrm{Chl}$ & Stp & $\mathrm{Mz}$ \\
\hline \multirow{9}{*}{ Gram ( -) bacteria } & E. coli & - & - & - & - & 1.0 & 1.0 & NT \\
\hline & E. coli(ATCC) & - & - & - & - & 1.0 & 1.0 & NT \\
\hline & S. enteritidis & - & - & - & - & 1.0 & 1.0 & NT \\
\hline & S. enteritidis ${ }^{\text {(ATCC) }}$ & - & - & - & - & 1.0 & 0.5 & NT \\
\hline & S. sonnei & - & - & - & - & 0.5 & 1.0 & NT \\
\hline & $P$. aeruginosa & - & - & - & - & 1.0 & 0.5 & NT \\
\hline & P. aeruginosa ${ }^{(\text {AтCC) }}$ & - & - & - & - & 1.0 & 0.5 & NT \\
\hline & S.marcenses & - & - & - & - & 0.5 & 0.5 & NT \\
\hline & K. pneumoniae & - & - & - & - & 1.0 & 0.5 & NT \\
\hline
\end{tabular}


Table 1 - Continuation

\begin{tabular}{|c|c|c|c|c|c|c|c|c|}
\hline & Microorganism & AE & SEA & NSEA & Berg & Chl & Stp & $\mathrm{Mz}$ \\
\hline \multirow{4}{*}{$\begin{array}{l}\text { Gram (+) } \\
\text { bacteria }\end{array}$} & E. faecalis & - & - & - & - & 3.9 & 2.0 & NT \\
\hline & E. faecalis(ATCC) & - & - & - & - & 3.9 & 2.0 & NT \\
\hline & S. aureus & - & - & - & - & 3.9 & 2.0 & NT \\
\hline & S. aureus (ATCC) $^{\text {(ATC }}$ & - & - & - & - & 3.9 & 2.0 & NT \\
\hline \multirow{5}{*}{ Yeast } & C. albicans & 312.5 & 156.3 & 19.6 & 4.9 & NT & NT & 0.031 \\
\hline & C. albicans ${ }^{(\mathrm{ATCC})}$ & 312.5 & 312.5 & 39.2 & 4.9 & NT & NT & 0.031 \\
\hline & C. guilliermondii & 312.5 & 312.5 & 39.2 & 9.8 & NT & NT & 0.031 \\
\hline & C. guilliermondii(ATCC) & 625.0 & 312.5 & 19.6 & 4.9 & NT & NT & 0.062 \\
\hline & C. tropicalis & 625.0 & 312.5 & 39.2 & 4.9 & NT & NT & 0.031 \\
\hline \multirow{5}{*}{ Filamentous fungi } & A. flavus & - & - & 312.5 & 625.0 & NT & NT & 0.122 \\
\hline & A. flavus ${ }^{(\mathrm{ATC} C)}$ & - & - & 312.5 & 312.5 & NT & NT & 0.031 \\
\hline & A. niger & - & - & 625.0 & 156.3 & NT & NT & 0.061 \\
\hline & A. nidulans & - & - & 625.0 & 312.5 & NT & NT & 0.061 \\
\hline & A. nidulans ${ }^{(\mathrm{ATCC})}$ & - & - & 625.0 & 312.5 & NT & NT & 0.062 \\
\hline
\end{tabular}

MIC values in $\mu \mathrm{g} / \mathrm{mL}$; - : inhibitory activity negative; NT: Not tested. Positive controls: Chl = chloramphenicol; Stp = streptomycin ; Mz = miconazole. Negative Controls: DMSO pure.

None of the samples, including the pure compound (bergenin), inhibited the tested Gram positive and Gram negative bacteria. The screening with filamentous fungi was also negative for the aqueous extract. Solely the non-soluble ethyl acetate fraction and bergenin have shown some activity, but it was considered very weak compared to the positive control. Miconazole had MIC of $0.293,0.146$ and $0.146 \mu \mathrm{M}$, respectively for $A$. flavus, $A$. niger, and $A$. nidulans, whereas bergenin had MIC of 1,093.0, 476.1, 951.9 $\mu \mathrm{M}$. No previous studies of bergenin were reported, except against plant pathogenic fungi, where difficulties of adsorption of bergenin in the plant tissues were found (Prithiviraj et al., 1997).

All samples were able to inhibit the growth of the all tested Candida species and clearly the inhibitory effect of the samples is associated with the presence of bergenin. Bergenin had MIC of 14.9, 14.9 and $29.8 \mu \mathrm{M}$, respectively for $C$. albicans, C. tropicalis and C. guilliermondii. Compared to the positive control, the MIC of miconazole was $0.074 \mu \mathrm{M}$ for all clinical isolated yeasts; this activity might be considered moderated. But the observed activity, along with the high content of bergenin found in the bark, help to explain the traditional use of $E$. uchi bark tea for the treatment of uterine infections, such as candidiasis, and other female disorders. The treatment of candidiasis is also considered one of the most successful alternative approaches against endometriosis, a female disorder that affects around 89 million worldwide (Ballweg, 2004).
The mechanism of action of bergenin is not known (Prithiviraj et al., 1997). Many phenol compounds isolated from plants show antifungal activity, including some gallic acid derivatives (Maillard et al., 1987; Singh et al., 1988; Da Silva et al., 2008) and bergenin is likely to act as these compounds.

Despite of the low activity found, it is important to notice that the efficacy of the traditional use of tea bark of Endopleura uchi could be confirmed. This shows the importance of the traditional knowledge and the study of medicinal plants in the Amazon.

\section{ACKNOWLEDGEMENTS}

We would like to thank CNPq and FAPEAM for their financial support and stipends, the CBA for the NMR spectral analysis, and Dr. George Nakamura for linguistic help in the preparation of this manuscript.

\section{LITERATURE CITED}

Ballweg, M.L. 2004. Impact of endometriosis on women's health: comparative historical data show that the earlier the onset, the more severe the disease. Best Practice \& Research Clinical Obstetrics and Gynaecology, 18(2): 201-218.

Braga, P.C.; Culici, M.; Alfieri, M.; Dal Sasso, M. 2008. Thymol inhibits Candida albicans biofilm formation and mature biofilm. International Journal of Antimicrobial Agents, 31(5): 472-477. 
Caldas, C.S.; De Simone, C.A.; Pereira, M.A.; Malta, V.R.S.; Carvalho, R.L.P.; Da Silva, T.B.C.; Sant'ana, A.E.G.; Conserva, L.M. 2002. Bergenin monohidrate, a constituent of Humiria balsamifera, at 120 K. Acta Chrystallographica, 58: 609-611.

Corrêa, M.P. 1984. Diccionario das Plantas Úteis do Brasil e das Exóticas Cultivadas. Rio de Janeiro, Imprensa Nacional, vol. 6, p. 326.

Da Silva, S.L.; Figueiredo, P.M.S.; Yano, T. 2006. Antibacterial and antifungal activities of volatile oils from Zanthoxylum rhoifolium leaves. Pharmaceutical Biology, 44(9): 657-659.

Da Silva, S.L., Figueiredo, P.M.S., Yano, T. 2008. Antimicrobial activity of ethanol extract from leaves of Casearia sylvestris (Flacourtiaceae). Pharmaceutical Biology, 46(5): 347-351.

Hoffman, H.L., Pfaller, M.A. 2001. In vitro antifungal susceptibility testing. Pharmacotherapy, 21(8): 111-123.

Hussain, A.I.; Anwar, F.; Sherazi, S.T.H.; Przybylski, R. 2008. Chemical composition, antioxidant and antimicrobial activities of basil (Ocimum basilicum) essential oils depends on seasonal variations. Food Chemistry, 108(3): 986-995.

Jahodar, I.; Kolb, I.,; Lioka, A. 1992. NMR spectral analysis of bergenin. Fitoterapia, 63(3): 260-261.

Lim, H.K.; Kim H.S.; Choi, H.S.; Oh, S.; Choi, J. 2000. Hepatoprotective effects of bergenin, a major constituent of Mallotus japonicus, on carbon tetrachloride-intoxicated rats. Journal of Ethnopharmacology., 72(3): 469-474.

Magalhães, L.A.; Lima, M.P.; Marinho, H.A.; Ferreira, A.G. 2007. Identificação de bergenina e carotenóides no fruto de uchi (Endopleura uchi, Humiriaceae). Acta Amazônica, 37(3): 447450.

Maillard, M.; Gupta, M.P.; Hostettmann, K. 1987. A new antifungal prenylated flavonone from Erythrina herteroana. Planta Medica, 53(6): 563-564.

Marx, F.; Andrade, E.H.A.; Zoghbi, M.G.; Maia, J.G.S. 2002. Studies of edible Amazonian plants. Part 5: Chemical characterization of Amazonian Endopleura uchi fruits. European Food Research and Technology, 214(4): 331-334.
Nazir, N.; Koul, S.; Qurishi, M.A.; Taneja, S.C.; Ahmad, S.F.; Bani, S.; Qazi, G.N. 2007. Immunomodulatory effect of bergenin and norbergenin against adjuvant-induced arthritis - A flow cytometric study. Journal of Ethnopharmacology, 112(2): 401405.

NCCLS- National Commitee For Clinical Laboratory Standards. 1990. Approved standard M7-45. Standard methods for diluition antimicrobial susceptibility tests for bacteria that grow aerobically, Villanova, $\mathrm{Pa}$.

Ogan, A.U. 1971. An isocoumarin from the bark of Sacoglottis gabonensis. Phytochemistry, 10(11): 2832-2833.

Piacente, S. 1996. Constituents of Ardisia japonica and their in vitro anti-HIV activity. Journal of Natural Products, 59(6): 565-569.

Prithiviraj, B.; Singh, U.P.; Manickam, M.; Srivastava, J.S.; Ray, A.B. 1997. Antifungal activity of bergenin, a constituent of Flueggea microcarpa. Plant Pathology, 46(2): 224-228.

Revilla. J. 2001. Plantas da Amazônia. Oportunidades Econômicas Sustentáveis. Manaus, INPA/SEBRAE, pp. 89-90.

Singh, U.P.; Pandey, V.B.; Singh, R.N.; Singh, R.D.N. 1988. Antifungal activity of some new flavonenes and flavone glycosides of Echinops echinatus. Canadian Journal of Botany, 66(9): 1354-1356.

Sumino, M.; Sekine, T.; Ruangrungsi, N.; Igarashi, K.; Ikegami, F. 2002. Ardisiphenols and other antioxidant principles from the fruits of Ardisia colorata. Chemical \& Pharmaceutical Bulletin, 50(11): 1484-1487.

Swarnalakshmi, T.; Seth Raman, M.G.; Sulochana, N.; Arivudainambi, R. 1984. A note on the antiiflammatory activity of bergenin. Current Science, 53(17): 917-917.

Takahachi, H.; Kosaka, M.; Watanabe, Y.; Nakade, K.; Fukuyama, Y. 2003. Synthesis and neuroprotective activity of bergenin derivatives with antioxidant activity. Bioorganic \& Medicinal Chemistry, 11(8): 1781-1788.

Recebido em 01/09/2008

Aceito em 08/05/2008 
